\title{
The Economic Role of the Region's Geobrand in Strengthening the Educational Trend of Foreign Youth Migration
}

\author{
Olga Popova1, Julia Myslyakova², and Nafisa Gagarina²
}

${ }^{1}$ Ural State University of Economics, Department of Marketing and International Management, Yekaterinburg, Russian Federation

${ }^{2}$ Ural State University of Economics, Department of Business Foreign Language, Yekaterinburg, Russian Federation

\section{Abstract}

The article considers the influence of the geobrand of Yekaterinburg and the Sverdlovsk oblast with regards to attracting foreign students to the universities in the region. It provides the statistics on the positive economic impact of the geobrand on the educational trend of foreign youth migration. What attracts foreign students is not only the university, but also the region itself. In case of Yekaterinburg, it is a well-known geobrand created historically purposefully or spontaneously. Large-scale international

Corresponding Author:

Olga Popova

so.popova63@mail.ru

Published: 21 January 2021

Publishing services provided by Knowledge E

(c) Olga Popova et al. This article is distributed under the terms of the Creative Commons

Attribution License, which permits unrestricted use and redistribution provided that the original author and source are credited.

Selection and Peer-review under the responsibility of the XXIII International Conference Conference Committee. events held in the region contribute a lot to the worldwide recognition of the geobrand. It attracts additional resources and determines the competitive position of the area both locally and globally. With the development of digital culture, information society and the media space, it is possible to increase the region's competitiveness and investment attractiveness. It is essential for improving its image and for its positive perception internally and externally. Since 2017 Yekaterinburg has been positioned mainly as a cultural and sports capital. Its image is transforming from that of an industrial territory to the image of a developing region. There are 39 higher education institutions located in Yekaterinburg, many of which occupy high positions in the Russian university ranking. Full-time contracts and part-time contracts with foreign students allowed the universities to receive income from the export of educational services. These universities managed to increase their total return on export of their services, which proves the interest of foreign students to studying in Ural universities. The main criteria for choosing the universities were recognition of the university diploma in their home country, interest in the region where the university is located and tuition fee. The sources of information from which they learned about the university were: Internet, World Cup and the university representatives visiting their country.

Keywords: export of educational services, economic impact of geobrand, educational migration, geotransformation.

\section{Introduction}

The importance of enhancing the educational trend of migration of foreign youth is reflected in the passport of the priority project "Development of the export potential of 
the Russian education system", approved by the Presidium of the presidential Council for strategic development and priority projects on 30.05.2017 and designed to increase the number of foreign citizens studying full-time in Russian universities from 200 thousand people (2017) to 710 thousand people (2025) [1]. This document proposes to improve the regulatory framework in the context of the admission and training of foreigners, the recognition of their diplomas; to promote the 'brand' of Russian education; to create favorable conditions for the foreign students' stay; to develop and implement the target model of the university activity for the export of education.

We believe that the center of attraction for foreign youth is not only the University, but also the region itself, which has a well-known geobrand, i.e., a complex set of unique properties historically formed purposefully or spontaneously, attracting additional resources and determining the competitive position of the territory not only in the country but also in the world. At the same time, with the development of digital culture, information society and media space there is an opportunity to increase the level of competitiveness and investment attractiveness of the city, improve its image, its positive perception by the external and internal audience [3]. If we take the Sverdlovsk oblast as an example, we can say it has a geobrand that dates back to the time of Peter I associated with the formation of the all-Ural mining center that was located at the favorable crossing of trade routes and had rich natural resources contributing to the growth of mining industry. Since then, Yekaterinburg being the heart of the Sverdlovsk region has changed its image, transforming it into a capital city open for communication. This geotransformation is manifested in creating the most favorable innovative climate, establishing information technology links, ensuring economic and environmental security, designing a developed infrastructure that meets international standards, and certainly in the cultural landscape, among other things, shaped by the local architecture. Part of the local architecture was inherited and the other part is being designed and built now creating a new image of the city for the future generations to live. In developing the geobrand of Yekaterinburg, emphasis is put on combining historical traditions and new trends in architecture, the beauty of old mansions and the rationalism of modern complexes. This stresses the historical significance of the area's origin. In addition, foreign young people may be interested in the capital of the Sverdlovsk region because of the geographical style of the Ural region with its mountain range, the Stone Belt that divided Europe and Asia. Its geographical position combined the economic interests of the West and the East, the different cultural and historical traditions of the settlements. Therefore, exclusive tourist routes become a metropolitan feature of the territory under consideration, forming a dialectical view of the city's history and allow you 
to draw conclusions about the ambiguous, but very well-known historical past. Content analysis of the official media shows that since 2017, Yekaterinburg has been positioned mainly as a cultural and sports capital. In 2018 there was an increase in the number of publications devoted to developing the city's infrastructure, the health system, tourism, and international cooperation [3].

This demonstrates the geotransformation of the Sverdlovsk region from the historically established image of the Ural old industrial territory - the "supporting edge of the state" to the image of a developing region with a modern capital with the features of a world megalopolis. Particularly important are 39 higher education institutions located in Yekaterinburg, many of which occupy high positions in the Russian university ranking in terms of the quality of educational services and the prestige of studying at them. In turn, this indicates the dynamic development of the region, its innovative course of history and the ability to attract young people, both from different parts of Russia and from different countries.

\section{Methodology and Methods}

If we turn to statistics, we can note the following positive economic influence of the geobrand of Yekaterinburg and the Sverdlovsk oblast on the educational trend of migration of foreign youth. Thus, in 2016-2017 academic year the universities of the Sverdlovsk oblast carried out 970 full-time contracts and 537 part-time contracts which allowed universities to receive income from the export of educational services worth of $151,462,435$ roubles. In the 2017-2018 academic year, the number of full-time contracts with foreign citizens increased by $157 \%$ compared to the previous year, which amounted to $203,614,764$ roubles. At the same time, the number of part-time contracts decreased by $87 \%$, which affected the university's return on export activities, which amounted to $33,776,250$ roubles in the 2017-2018 academic year. A positive point here is the fact that, despite the different trends in export services, universities managed to increase their total return from $151,462,435$ roubles to $237,391,014$ rubles a year, which proves the interest of foreign students to coming and studying in Ural universities.

In the university context, see table 1, in the 2017-2018 academic year, the Ural Federal University has the highest return on the export of educational services. (158 million rubles) due to full-time and part-time contracts with foreign students (Table 1).The calculation is based on [4]. This is because engineering and technical specialties have always been more in demand (in the 90 s of the last century $53 \%$ of the total number of 
trained foreign citizens in state Russian universities studied in these specialties). This choice priority remains to the present.

TABLE 1: Export of educational services of state universities of the Sverdlovsk oblast in the 2017-2018 academic year [5]

\begin{tabular}{|c|c|}
\hline $\mathbf{N}^{\circ}$ & University \\
\hline 1. & $\begin{array}{l}\text { Ural Federal } \\
\text { University named } \\
\text { after the first } \\
\text { President of } \\
\text { Russia B.N. Yeltsin }\end{array}$ \\
\hline 2. & $\begin{array}{l}\text { Ural State } \\
\text { University of } \\
\text { Economics }\end{array}$ \\
\hline 3. & $\begin{array}{l}\text { Ural State Mining } \\
\text { University }\end{array}$ \\
\hline 4. & $\begin{array}{l}\text { Ural State } \\
\text { Pedagogical } \\
\text { University }\end{array}$ \\
\hline 5. & $\begin{array}{l}\text { Ural State Law } \\
\text { University }\end{array}$ \\
\hline 6. & $\begin{array}{l}\text { Ural State } \\
\text { Forestry } \\
\text { University }\end{array}$ \\
\hline 7. & $\begin{array}{l}\text { Ural State } \\
\text { University of } \\
\text { Architecture and } \\
\text { Art }\end{array}$ \\
\hline \multicolumn{2}{|c|}{ Total } \\
\hline & roubles \\
\hline
\end{tabular}

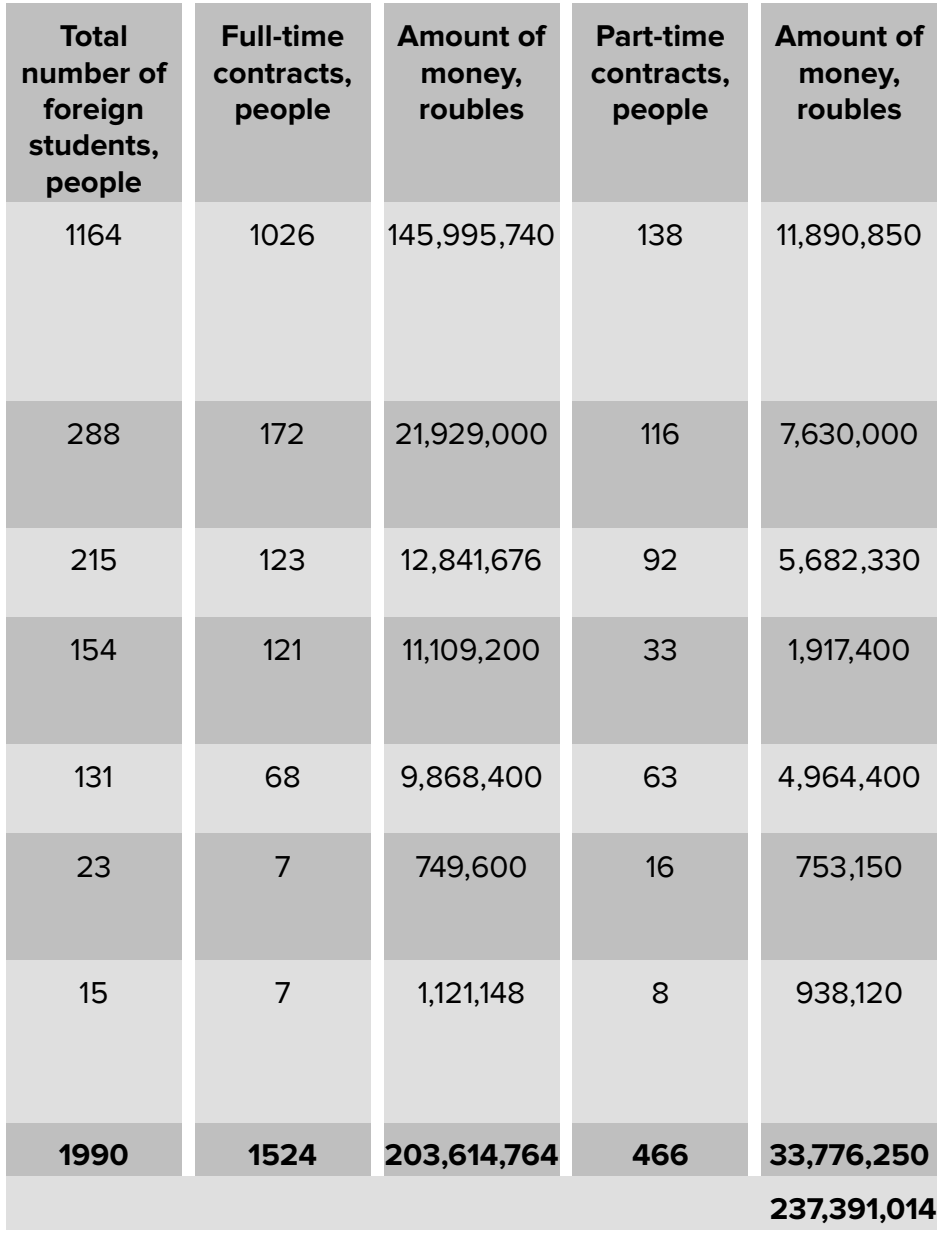

The Ural State University of Economics ranks the second in terms of return on the export of educational services to foreign citizens ( 29.5 million rubles). This is explained by the demand for economic specialties; high quality training, which forms a long-term base of the image of the university. The Ural State Mining University ranks the third. Training foreign citizens provided an inflow of 18.5 million roubles. The attractiveness of studying mining is explained by the specifics of educational programs (even in Russia, mining engineers are trained only by Moscow State University and St. Petersburg State University) and the subsequent demand for the graduates in large US companies.

It should also be noted that compared to the previous period (academic year 20162017) the number of foreign students has grown significantly, which also illustrates the influence of the Yekaterinburg geobrand on strengthening the educational trend of youth migration. Ural Federal University, Ural State University of Economics, Ural State 
Mining University are also at the top in the ranking of the leading universities in the Sverdlovsk oblast in terms of return on full-time contracts with foreign students.

\section{Results and Discussion}

Consider the activities of the Ural State Economic University in the field of international relations and export of educational services. In 2007, USUE entered the register of higher education institutions in Germany in the highest $\mathrm{H}+$ category. The University's diploma was recognized in Europe.

In 2018 the Ural State University applied to become a member of the Consortium of universities that export Russian education, in order to further successfully attract foreign students to the region and develop the infrastructure of Yekaterinburg as an international youth platform. The Association of Foreign Students in Russia operates in USUE.

Throughout its activity the university has signed over 110 international cooperation agreements in 41 countries (Ecuador, Mexico, Uruguay, Guatemala, Paraguay, Benin, Equatorial Guinea, Gabon, Nigeria, Congo, Egypt, Iraq and other) including agreements on developing a double degree program in four bachelor's degrees and two master's degrees at six universities. Twenty-three professors from the United Kingdom, France, Germany, the United States, the Czech Republic, China, Ecuador, Benin, Equatorial Guinea and other countries have the title of "Honorary Professor of USUE".

According to the monitoring of the Russian universities' effectiveness, USUE's international performance indicator is at $4.44 \%$ a minimum threshold being $1 \%$ [6].

In the 2017-2018 academic year 492 students from 45 countries studied at Ural State Economic University. In the 2018-2019 academic year there were 525 students from 50 countries. At present, the university is training 536 foreign students from 52 countries. Among them: $10 \mathrm{CIS}$ countries (Armenia, Azerbaijan, Belarus, Kazakhstan, Kyrgyzstan, Moldova, Tajikistan, Turkmenistan, Uzbekistan, Ukraine), 39 non-CIS countries (Bulgaria, Brazil, Vietnam, Mongolia, China, India, South Korea, Turkey, Benin, Guinea, Zimbabwe, Cameroon, Congo, Côte d'Ivoire, Mali, Nigeria, Senegal, Equatorial Guinea, Morocco, Egypt, Gabon, Gambia, Zambia, Libya, Liberia, Sudan, Sierra Leone, Tunisia, Uganda, Afghanistan, Syria, Iraq, Yemen, Latvia, Poland, France, Italy, Ecuador).

Geographical growth was provided by Asian countries such as India, South Korea, Turkey, by African countries such as Gabon, Gambia, Zambia, Libya, Liberia, Sudan, Sierra Leone, Tunisia, and Uganda and by the European country of Bulgaria. 
A survey of 150 foreign USUE students was conducted to determine the criteria for choosing a university. The main criteria were recognition of the university diploma in their home country (100\%), interest in the region where the university is located (95\%), tuition fee $(54 \%)$, recommendations of relatives, friends and acquaintances $(20 \%)$. Sources of information from which they learned about the university: Internet (100\%), World Cup (92\%), the university representatives visiting their country $(68 \%)$, international events, held in Yekaterinburg (40\%).

USEU is actively working to attract and adapt foreign students. Since 2014, the Testing Center for Foreign Citizens has been operating at the University of Economics, which allows residents of foreign countries to improve their knowledge of the language, history and legislation of Russia, as well as adapt to work and permanent residence in the country.

The Ural State University operates a Preparatory Department for foreign citizens. There are three educational program specializations: economic, medical, and technical. The medical educational program specialization is provided based on the agreement to train applicants for the Ural State Medical University. The technical educational program specialization is provided in accordance with the agreement with the Ural State Forestry University. The preparatory faculty has the necessary classroom and library facilities for teaching Russian to foreign citizens.

The University is actively expanding the geography of student and teacher exchange programs. It is establishing friendly and partnership relations with other universities and with representatives of various public authorities of foreign countries. One-semester academic mobility programs are an integral part of the USUE international activities. In 2019, USUE had 38 exchange program students (Jean Moulin Lyon 3 University, University of Western Brittany, Narxoz University, Harbin University of Commerce, University of Verona, Hanoi University, and Osh Technological University).

Foreign students take an active part in organizing and holding a number of international events, such as the all-Russian Sports Olympiad among foreign students of Russian universities; the annual "Eurasian Economic Youth Forum: Asia-Russia-Africa: the economy of the future", the Russian-Chinese Congress of Young Entrepreneurs in the framework of the Russian-Chinese EXPO.

Every year, the Ural State University of Economics hosts the Festival of Cultures "Around the World in 7 Days" - a series of events united by intercultural themes. During a week, students present their culture, traditional cuisine and movies made in their country. 
In order to increase the interest of USUE students to international activities, the "Hour of a Diplomat" was organized at which the Consuls of Belarus, Azerbaijan, Kazakhstan, Hungary, China, Spain, France, and China spoke at the University. The Ambassador Extraordinary and Plenipotentiary of Benin to the Russian Federation, Anicet Gabriel Kotchofa, opened the project.

Throughout their studies, students learn the Russian language in depth, starting from the zero level; are acquainted with the traditions, culture and specifics of living in Russia. They actively participate in city and University events, which help them to be completely immersed in students' life.

For students to adapt to the new socio-linguistic and cultural environment the university arranges offsite events, visiting museums and significant historical sites in Yekaterinburg and the Sverdlovsk oblast.

To promote USUE educational services abroad, the university organizes trips of its representatives to Kazakhstan, Uzbekistan, Tajikistan (Representative office of Rossotrudnichestvo, schools, educational exhibitions), Kyrgyzstan (Ministry of Education and Science of Kyrgyzstan, schools, gymnasiums), Thailand (The University of the Thai Chamber of Commerce (UTCC), Ramkhamhaeng University (RU), Panyapiwat Institute of Management), Turkey (educational exhibition), Czech Republic (Institute of Technology and Business in České Budějovice), Poland (Representative office of Rossotrudnichestvo in Poland, Russian center of science and culture), France ( Jean Moulin Lyon 3 University, Lyon), China (educational exhibition), Bulgaria (University of Management, Varna).

USUE is a full member of international and regional associations: Association "Eurasian Economic Club of Scientists", European Retail Organization (ERA), European Association of Leading Business Schools of Hotel Management (EURHODIP), Association of Eastern and Central European Business Schools (CEEMAN), the National Committee for the Promotion of Economic Cooperation with Latin America and others.

\section{Conclusions}

1. The economic role of the region's geobrand is an essential criterion for foreign students when choosing a University. In the first place is the recognition of the university diploma in their country.

2. Due to the transformation of the image of Yekaterinburg as an industrial city and positioning it as a cultural and sports capital with a developed infrastructure and 
a city involved in international cooperation, the educational trend of migration of foreign youth to higher education institutions in the region is increasing.

3. A well-structured media policy both of the region and the university allows attracting foreign students and developing the export potential of the Russian education system.

\section{References}

[1] Government of the Russian Federation. Passport of the Priority Project "Development of the Export Potential of the Russian Education System." (2017). Retrieved January 26, 2020 from http://government.ru/news/28013/.

[2] Ministry of International and Foreign Economic Relations of the Sverdlovsk Region. Strategy for the Development of International and Foreign Economic Relations of the Sverdlovsk Region to 2035. (2019). Retrieved February 02, 2020 from http: //mvs.midural.ru/strategiya-razvitiya-mezhdunarodnykh-i-vneshneekon.

[3] Kalyuzhnaya, E. and Popova, O. (2019). Media Image of the City in the Context of Digital Culture. Presented at 3rd Conference on Post Mass Media in the Modern Informational Society (PMMIS)-Journalistic Text in a New Technological Environment-Achievements and Problems. Chelyabinsk, Russia. EpSBS, 66, Pp. 397-405. Future academy (online).

[4] Ministry of Science and Higher Education of the Russian Federation. (2019). Center for Sociological Research Education of Foreign Citizens in the Educational Organizations of the Higher Education of the Russian Federation: Statistical Collection. Issue 16).

[5] Ministry of Science and Higher Education of the Russian Federation. (2019). Export of Russian Educational Services: Statistical Collection. (Issue 9). Moscow: Center for Sociological Research, p. 536.

[6] Monitoring (High. Edu.). (2019). Retrieved January 17, 2020, from InformationAnalytical Materials on the Results of Monitoring the Effectiveness of Educational Institutions of Higher Education. website: http://indicators.miccedu.ru/monitoring/ 2019/_vpo/inst.php?id=315 